possible. But what is still more puzzling is how Prof. Carnelley succeeded in burning his fingers with the ice. Our previous knowledge would lead us to suppose that the outside surface of the block of ice was a free surface, and that therefore it would be impossible, however high the temperature of the inside of the block, to heat the outside above the "melting point," as we should expect the ice to melt or to sublime at the outside, and keep the temperature at $0^{\circ} \mathrm{C}$

These expectations being disappointed, we naturally look to the decreased pressure under which Prof. Carnelley's experiments were made for an explanation of this most unexpected state of matters. Now it is very evident that when dealing with pressures of about one atmosphere, and with temperatures of $120^{\circ}$ and $180^{\circ} \mathrm{C}$., that pressure, as pressure, has nothing whatever directly to do with the "melting point" of the ice. While this is the case, it is equally evident that it has a most important influence on the surroundings of the ice. At the pressure of $4^{\circ} 6 \mathrm{~mm}$., at which the experiments were made, no water would be present, there would be nothing but ice and water-vapour. Here then appears to be the great teaching of Prof. Carnelley's experiments. They show that the surface of ice bounded by its own vapour is not a "free surface." This result is so very unexpected that much consideration will be necessary before we can re-arrange our ideas to meet the new facts.

We might imagine that nothing could be more free than the surface of a body bounded by nothing but its own vapour, yet Prof. Carnelley's experiments seem to say it really is not co, and not being a "free surface," we of course know nothing whatever of how high the temperature will require to be before the ice will melt under these conditions.

These experiments of Prof. Carnelley's are so interesting that we wait with impatience a full description of them. His results indicate something new with regard to the influence of a liquid on its melting solid. I observe that Prof. Carnelley's results are doubted by most of your correspondents, but for the present we must accept them when Prof. Carnelley distinctly states that the temperature of the ice was taken by means of a thermometer in contact with the ice.

Darroch, Falkirk, N.B., October 30

\section{Wire Torsion}

IN the letter in NATURE, vol. xxii. p. 604, which we wrote at the request of Major Herschel, who asked for information regarding the connection between tensional and torsional strains of a brass wire, we mentioned that there were many papers scattered through the Proceedings of learned societies dealing with the fluidity of metals. There is one communication to which we might specially have referred, as it deals in particular with the torsional yielding of wires under tension, and this is a paper on "Torsion," by Prof. G. Wiedemann, in the Annalen der Physik und Chemie, No. 4 vol. vi., 1879, pp. 485-520, and of which a translation is given in the Philosophical Magazine, vol. ix., January 1880, pp. 1-15, and February, pp. 97-109. The first part of this paper gives a detailed account of experiments which show :-(I) That a brass wire often subjected to a particular torsion, either in one or in both directions, becomes "killed" for any less torsions, that is, follows Hooke's law for its temporary torsions; (2) that a wire under tension acquires greater torsional set from a given torsional couple than when the wire is unextended; (3) that a wire under even considerable tension may be killed by torsion in alternately opposite directions, that is, it will obey Hooke's law for any tension or torsion less than the stresses actually applied originally. Prof, Wiedemann in the second part of his paper considers the wellknown "agitation effects," and enters on an explanation of the phenomenon based upon molecular allineations referring to the magnetisation theory of Weber and Kolrausch which is based on the same idea.

The strains in Prof. Wiedemann's wires were however much less than in those used in Major Herschel's experiments.

London, November 8

JOHN PERRY

W. E. Ayrton

\section{Heat of Formation of a Compound}

IN NATURE, vol. xxii. p. 608 , there is a paper on "Recent Chemical Research," in which under the head of work by Thomsen the following law is enunciated :-

"The heat of formation of a compound substance is the difference between the sum of the heats of combustion of the constituent elements of the compound and the heat of combustion of the compound itself." After that it is shown that this is not the true heat of formation of the compound, as many important corrections have to be made. On referring to Bertbelot's "Essai de Mécanique Chimique" I find the following:- "The heat of formation of an organic compound from its elements is the difference between the sum of the heats of total combustion of its elements and the heat of combustion of the compound with formation of identical products."

Can any of your readers inform me whether Thomsen or Berthelot first enunciated this law?

Another point is, that Berthelot apparently makes no reference to the corrections for the heat absorbed in dissociating the molecules of the elements, \&c.

Edinburgh, November I

A. P. LAURIE

The Yang-tse, the Yellow River, and the Pei-ho

IN replying to the letter of your correspondent (NATURE, vol. xxii. p. 559) on the subject of my recent paper on these three rivers, I have to thank him for his very probable explanation of the excessive estimate made by Sir George Staunton of the amount of sediment discharged by the Yellow River.

The estimate given in my paper of the water-discharge of the River Plate is ipso facto an assumption made by $\mathrm{Mr}$. George Higgin from Mr. Bateman's calculation of the minimum flow of that river, which he found to be 670,000 cubic feet per second. It might have been better, however, if I had added Mr. Higgin's qualifying remark that such an estimate of the mean volume of water was "very much under the mark" (NATURE, vol. xix. p. 555).

The anomaly of the surface current varying in velocity with the same average depth of water has not been unnoticed by myself, though I am unable to give a satisfactory explanation of the difficulty.

Woodlane, Falmouth, November 6

H. B. GuPPY

The Thresher

WHAT is the "thresher"? It is generally assumed to be the fox-shark (Alopias vulpes), but in a recent number of Land and Water-which I have only just seen-Mr. Frank Buckland says that he believes it to be "the gladiator dolphin or sword grampus" (Orca gladiator). This he infers from a drawing of Lord A. Campbell's, of which he gives a cnpy. The tail, he says, is not that of the fox-shark. But as it is heterocercal it cannot be that of a grampus or any other Cetacean. Whatever it is I suppose that there is no doubt that it throws itself out of the water ("high as the masthead" [of a trawler] one of $\mathrm{Mr}$. Buckland's correspondents avers). Does it do so more than once? Once, many years ago, between Sydney and New Zealand, I saw, what they said was a fight between a thresher and a whale, but there was nothing to be 'seen beyond a splashing of the water. Last year off Lisbon I witnessed a similar event. Does the sword-fish also attack the whale? Lord A. Campbell, in the letter accompanying his drawing, estimated the length of his thresher at " upwards of thirty feet ;" this is twice the length given by Yarrell.

Francis P. PASCOE

October 30

Since the above was written I see that Dr. Günther, in his new work on Fishes, says : "Statements that it (the fox-shark) has been seen to attack whales and other large cetaceans rest upon erroneous observations" (p. 322).

“Student" should refer to Newcomb's "Popular Astronomy "with respect to the larger telescopes. For results he must refer to the publications of the Royal and Astronomical Societies, the Washington Observatory, \&c.

PaUl Lafargue.-We regret we have no further details on the labours of the U.S. Fish Commission in increasing the food supply of the country.

ILLUSTRATIONS OF NEW OR RARE ANIMALS IN THE ZOOLOGICAL SOCIETY'S LIVING COLLECTION

I.

THE sagacious founders of the Zoological Society of London made it a special rule that no dividends or gifts of any kind should be distributed amongst the 